\title{
THE TRAGEDY OF TRANSITION: DEVELOPMENT, DETERIORATION, DECAY. THE CASE OF HUNGARY, 1990- 2020
}

\section{Bokros, L.}

Lajos Bokros / Central European University, Quellenstraße 51 | A-1100 Wien, Austria. Email: Bokrosl@ceu.edu.

\begin{abstract}
The essay is about the economic and political development of Hungary in the last 30 years. It can be neatly divided into three periods which coincide with the calendar decades almost perfectly. After the collapse of the communist system, the first period constituted a glorious decade in development: the first two governments implemented almost all indispensable structural reforms required for a successful transition. After the financial stabilization in 1995, a consistent macroeconomic policy was applied, leading to export and investmentdriven, hence sustainable economic growth. The next decade brought deterioration: reforms were stalled, and a sharp turn to consumption-led and debt-fuelled growth resulted in twin deficits which, by the time of the Great Recession, almost triggered a sovereign debt default. After a short period of successful financial stabilization, a populist-nationalist government came to power in 2010. A decade of decay set in: reversal of structural reforms, nationalization, monopolization, protectionism, market-distorting taxation and subsidization, state capture by a corrupt oligarchy, together with inconsistent macroeconomic policy. In addition, the self-styled „illiberal regime” of Viktor Orbán demolished the rule of law and all institutions representing checks and balances in a democracy. Corruption was elevated to the level of official government policy. With the help of the huge amount of subsidies coming from the EU, the regime maintained financial equilibrium and achieved significant growth during the time of global boom between 20142019. However, given the fact that private investments and productivity stay rather low in the non-tradable sector of the domestic economy, real convergence to Western efficiency and living standards remain elusive. Today Hungary constitutes a primary example of an economy pushed into a typical middle-income trap by its oligarchic and authoritarian regime. It also proves that transition reforms are all reversible; institutions are fragile. Restoration of the rule of law and democracy seems to be an indispensable prerequisite for convergence and development.
\end{abstract}

Keywords: development; deterioration; decay; Hungary, economic development, rule of law

JEL Classification: P20, M20 


\section{Introduction}

The revolution of Hungarian society against Stalinist communism and Soviet domination in the fall of 1956 was a high point in modern Hungarian history. Even though the uprising was unsuccessful and soon brutally suppressed by Soviet troops, the events unfolding in a small country of Central and Eastern Europe (CEE) were undoubtedly of global significance. Apart from sporadic and localized revolts against specific measures of the communist authorities (Berlin, Plzeň, 1953), this was the first nationwide, open and complete repudiation of everything Stalinism represented in one of the CEE-countries incorporated into the Soviet empire after WWII. Some of the best analysis of the Hungarian 1956 in the English language can be found in Lomax (1976), Gati (2006) and Brown (2010)1.

The outburst of dissatisfaction in Hungarian society was triggered by the start of the historic thaw in the Soviet Union and the workers' revolt in Poznań, Poland. People noticed the ongoing power struggle in the Soviet Communist Party and the growing uncertainty among party leaders in the whole Communist bloc. As we know from Tocqueville, revolutions are more likely to occur when despotic regimes start introducing reforms, and the people realize how bad their fate used to be before. ${ }^{2}$ This is exactly what happened in Hungary.

Although the Hungarian revolution was ruthlessly suppressed in November 1956, it definitely altered the course of history for the small country forever. The complete neoStalinist restoration was considered impossible even by the new leaders of the reconstituted Communist Party. János Kádár, the chief architect of the puppet regime, proved to be less than a servile puppet of the Soviet Union. After a few years of repression, the party started designing and then implementing a fundamental economic reform of the rigid Stalinist command economy.

The new economic management system, with the purposefully unassuming name New Economic Mechanism (NEM) undertook a wholesale liberalization of inter-enterprise relations without giving up the basic tenet of socialism: dominant state property in the means of production. ${ }^{3}$ The reforms abolished mandatory central planning by physical targets, introduced financial regulation (albeit in a highly individualized manner), allowed much more consumer autonomy and partially restored the labour market. ${ }^{4}$ But the most important feature of these reforms was that they survived the suppression of the Prague Spring in 1968. Apart from the Yugoslav market-oriented model, the Hungarian NEM constituted the only successful economic reform in the whole Soviet bloc, which lasted until the very end of communism in CEE without any irreversible step of regression.

\footnotetext{
${ }^{1}$ pp.278-292

2 „Going from bad to worse does not always mean a slide into revolution. More often than not, it occurs when a nation which has endured without complaint - almost without feeling them - the burdensome laws rejects them with violence the moment the weight of them lightens. The regime destroyed by a revolution is almost always better than the one that immediately preceeded it..." (de Tocqueville, 2008, p.175).

${ }^{3}$ The best and most comprehensive description of Hungarian economic reforms under the communist system can be found in Berend (2010).

${ }^{4}$ A more detailed analysis of these significant changes is provided by Bokros (2021a), chapter 4.3. Reform $=$ Retreat, pp. 103-112.
} 


\section{DISCUSSION}

Twenty plus years of economic liberalization brought about a significant increase in the living standard for the people in Hungary and could not but have a major impact on politics and culture as well. The totalitarian system ceased to exist; people regained considerable freedom in conducting their private affairs. Travel to the East was almost completely free; to the West, it was regulated in a much more predictable manner. The slogan of Kádár was that "who is not against us is with us". That was an obvious change from the Stalinist concept, which formulated the slogan in a sharply exclusionary manner: "who is not with us is against us".

Of course, it was not always smooth sailing. After the introduction of martial law in Poland in December 1981, foreign currency deposits were withdrawn from the NBH. With no Soviet financial help in sight after the botched military intervention in Afghanistan, Hungary joined the IMF and the World Bank the next year and started a new wave of reforms by allowing the establishment of small-scale private businesses and joint ventures with foreign firms.

When Gorbachev initiated glasnost and perestroika in the Soviet Union after 1985, Hungarian communist leaders took notice. Some of them realized that it created an opportunity to implement even more significant market reforms. Although these late reforms still stopped short of challenging the dominance of state property, they led to further liberalization and even to some competition (the creation of a two-tier banking system in 1987, the introduction of personal income tax (PIT) and value-added tax (VAT) in 1988, allowing the election of senior management in SOEs, etc.) These steps were driven by the increasingly unsustainable foreign debt burden, which threatened the state with default. ${ }^{5}$

In this short essay, I will analyze the economic and political transition of Hungary in the last thirty years. This rather long historical period can be divided into three distinct subperiods which - interestingly - coincide with the calendar decades almost perfectly. The first one, until the end of the century, was characterized by rapid reforms and institution building: the country successfully introduced most structural reforms, which are considered indispensable for a small and open economy wishing to converge to Western productivity and living standards. ${ }^{6}$ The second period, between 2001-2010, can be regarded as a phase of deterioration. Structural reforms practically stopped, and the emerging new political class felt it not only possible but desirable to throw responsible fiscal policy in the wind. As Hungary approached and passed the date of EU accession, the thickening flow of EU subsidies made it possible to abandon macroeconomic policy consistency. Wasteful overspending coupled with widespread corruption started to become a major problem. Then came the Great Recession, which struck the Hungarian economy in a much vulnerable economic position: one week after the collapse of Lehman Brothers (September 15, 2008),

\footnotetext{
5 It is not to forget that Hungary had by far the largest foreign debt in per capita terms at that time. After the insolvency of Poland (1982), international markets expected a similar fate for Hungary (Mong, 2012).

6 I constructed a matrix of structural reforms which can be regarded as indicating most reforms absolutely indispensable in transition. For the last 25 years I considered all these reforms so closely interrelated that they constitute what I call the critical mass of reforms. That is perhaps an eloquent expression of the policy message that it is impossible to pick and choose only the popular ones and postpone or reverse the unpopular ones. For economic transition to be completed, all these reforms are to be introduced in such a way that they enhance their mutually reinforcing positive impact (Bokros, 2013).
} 
the government of Hungary was obliged to ask for financial assistance from the EU the IMF and the World Bank.

The third phase covers the period of 2010-2020, ten years perfectly matching the second decade of the new century. This period is, without doubt, the epoch of decay. Not only economic policy consistency was proudly given up, but the populist-nationalist regime of Viktor Orbán demolished the Rechtsstaat (the rule of law), destroying all important institutions of the new representative democracy. In addition, corruption and theft have become official government policy. Finally, the regime, which has been benefiting enormously from the huge subsidies of the EU, allied itself closely with Russia and China, effectively undermining the unity and security of the EU. A new oligarchy emerged around the prime minister, which captured the Hungarian state and entrenched itself against any possibility of democratic change. The new regime, proudly calling itself an embodiment of an "illiberal democracy" has become a prototype of populist-nationalist regimes, which is now followed by Poland, Turkey, and most countries of Central Asia. Since the rule of law is absolutely indispensable for economic convergence, the present state of affairs in Hungary constitutes an impediment to development.

\section{Development (1990-2000)}

Hungary was considered a star performer and a model to be followed not only from the viewpoint of political transition but for some time in terms of economic transition, too. While the peaceful political transition to multiparty democracy was almost impeccable and, hence, considered almost a best practice pattern (Tökés, 1996), the consistency of economic reforms introduced by the first two democratically elected governments were also regarded as quite successful for a period of time.

The history of transition has taught us that initial conditions mattered a lot (Balcerowicz, 1995). In this respect, Hungary was in a fortunate position. The halfway marketization of the economy, achieved by NEM, resulted in conducting not only half of foreign trade with the West but, more importantly, in a remarkable change of attitudes toward market culture. Tens of thousands of leaders of not only state-owned enterprises (SOEs) but also that of small private ventures did learn important skills relevant to a capitalist market economy. Intellectual openness to market mechanisms and to democratic practices may have contributed significantly to the relatively smooth, peaceful and consensual transition of Hungary (Kornai, 2008).

The first eight years of transition made the substance of this glorious decade. The first democratically elected government ${ }^{7}$ implemented hugely important supply-side reforms. The most important steps can be considered the following:

1. The democratic government quickly reconstructed the already existing State Privatization Agency (SPA) in order to push forward privatization. Hugely

\footnotetext{
7 It was a center-right government dominated by the Hungarian Democratic Forum (MDF) led by József Antall, a renowned historian with a conservative and liberal family background. Sadly, he could not finish his term. He got seriously ill with cancer and succumbed to the fatal disease in December, 1993.
} 
significant that Hungary avoided the pitfalls of mass privatization schemes, which proved so detrimental in all countries which applied it. ${ }^{8}$

2. Hungary opted for the classical methods of privatization: selling control in SOEs to reputable strategic investors, most of them unavoidably foreign. Thus, a huge amount of FDI was channelled to the economy within a short period of time. Hungary received $50 \%$ of all FDI in CEE in 1991-1996.

3. Apart from greenfield investments, the huge influx of fresh capital was channelled to former SOEs in order to help their fast modernization by a recapitalization. This method made it possible for many former SOEs to survive the transition to the capitalist market economy.

4. Despite the extremely high level of foreign debt and sirene songs to opt for default, the government decided to avoid it by all means. That was a hugely beneficial decision given the fact that such a step would have stopped privatization and the influx of FDI for a long period of time.

5. Instead of mass privatization or reprivatization, the government issued so-called compensation coupons and allocated them to several groups of eligible people. Legislation awarded coupons not only to those who lost their property but also to those who lost their liberty and suffered persecution.

6. By being hugely degressive, coupons compensated eligible people only to a symbolic degree. Society welcomed the underlying message: all people suffered from fascism and communism, and larger compensation to some would have meant a larger additional burden to the rest of society.

7. Small and medium-sized enterprises (SMEs) were established by the tens of thousands and received all help from the advancing privatization process. Small scale standalone units were carved out from large bureaucratic SOE networks and sold to employees with the help of preferential loans.

8. The Antall government introduced high-quality legislation (and improved others) to support the move towards supply-side adjustment. The most notable laws dealt with privatization, bankruptcy and liquidation, commercial banking, securities trading, accounting and loss absorption (for a more detailed analysis, see Bokros, 2014, 2015).

The quick and quality action to stimulate supply-side adjustment resulted in a relatively smooth economic transition, especially if compared to the fate of other countries. Real GDP declined only for four years between 1990-1993, and the aggregate loss was no more than $20 \%$. Inflation shot up but exceeded $30 \%$ only in a single year (1991). Unemployment went up to $12 \%$ and remained above $10 \%$ for an extended period of time. (Obviously, the unavoidable short-term impact of privatization was shedding labour as a consequence of most SOEs having been loss-makers because of over employment and low productivity.)

${ }^{8}$ The horrible experience of mass privatization is best summarized by Ježek (1997). 
All phenomena detectable in a transitional crisis were present in Hungary in this period, but it is remarkable that the crisis was much less deep than in any other country in CEE.

There was one key area where the government failed to do its necessary homework: it postponed, time and again, the much required fiscal adjustment. After some tentative and early steps in 1991, which triggered a major upheaval (taxi drivers strike and traffic blockade) the Antall-government refrained from undertaking any significant change in fiscal redistribution and income support which had earned the label for Hungary that it had a premature welfare state. ${ }^{9}$

The moment of truth arrived in Hungary after the second democratically elected government took power in late spring 1994. It was a centre-left coalition with the dominant position of the reconstructed socialist party, which had gained an absolute majority in the elections but decided to enter into a coalition with the liberal Alliance of Free Democrats. International capital markets started to speculate about the spreading of sovereign default in the second half of the same year. After the tequila crisis of Mexico ${ }^{10}$, which started in December 1994, it was only a question of time when Hungary would follow.

"The stabilization package, announced after an extraordinary government meeting held on Sunday, March 12, 1995, was deliberately tailored in such a way that it wanted to improve the financial equilibrium very quickly but, at the same time, avoid pushing the economy once again into a deep recession. The intention was to break the vicious cycle of the past twenty or so years when Hungary used to have either a not too high economic growth with a quickly deteriorating financial position or a somewhat restrictive economic policy aimed at restoring primarily external financial equilibrium but resulting immediately in stagnation or even a decline of output." (Bokros, 1998, pp. 250-251)

In light of the above, the specific elements of the stabilization program were the following:

1. An upfront $9 \%$ devaluation of the Hungarian currency (HUF) to reach an equilibrium rate of exchange. Even more important, the National Bank of Hungary

\footnotetext{
9 János Kornai, the famous Hungarian economist introduced this eloquent phrase first to describe the unique situation in Hungary. He advocated for reforms of the welfare state in all postsocialist societies (Kornai, 1997).

10 During the 1994 presidential election, the incumbent administration embarked on expansionary fiscal and monetary policy. The Mexican treasury began issuing short-term debt instruments denominated in domestic currency with a guaranteed repayment in U.S. dollars, attracting foreign investors. Mexico enjoyed investor confidence and new access to international capital following its signing of the North American Free Trade Agreement (NAFTA). However, a violent uprising in the state of Chiapas, as well as the assassination of the presidential candidate Luis Donaldo Colosio, resulted in political instability, causing investors to place an increased risk premium on Mexican assets. In response, the Mexican central bank intervened in the foreign exchange markets to maintain the peso's peg to the U.S. dollar by issuing dollar-denominated public debt to buy pesos. The peso's strength caused demand for imports to increase in Mexico, resulting in a trade deficit. Speculators recognized an overvalued peso and capital began flowing out of Mexico to the US. Mexico purchased its own treasury securities to maintain its money supply and avert rising interest rates, drawing down the bank's dollar reserves. Supporting the money supply by buying more dollardenominated debt while simultaneously honoring such debt depleted the bank's reserves by the end of 1994. The central bank devalued the peso on December 20, 1994, and foreign investors' fear led to an even higher risk premium. To discourage the resulting capital flight, the bank raised interest rates, but higher costs of borrowing merely hurt economic growth. Unable to sell new issues of public debt or efficiently purchase dollars with devalued pesos, Mexico faced a default. Two days later, the bank allowed the peso to float freely. The Mexican economy experienced inflation of around $52 \%$ and mutual funds began liquidating Mexican assets. The effects spread to economies in Asia and the rest of Latin America. The U S organized a $\$ 50$ billion bailout for Mexico in January 1995, administered by the IMF with the support of the G7.In the aftermath of the crisis, several of Mexico's banks collapsed amidst widespread mortgage defaults. The Mexican economy experienced a severe recession and poverty and unemployment increased. https://en.wikipedia.org/wiki/Mexican_peso_crisis
} 
(NBH) introduced a preannounced crawling peg mechanism with ever-smaller rates for monthly devaluations in the name of predictability.

2. The introduction of a temporary import surcharge of $8 \%$ was aiming at generating an additional $1.5 \%$ of fiscal revenue. It was also announced that it would be reduced every half a year by $2 \%$ points and phased out completely by mid- 1997 . Predictability was strengthened further by this.

3. While devaluation is a general device, an import surcharge can be applied selectively. It was not levied on primary energy to avoid higher inflation. Direct import components for exported goods and imported investment goods (machinery) were also exempted.

4. This specific mix of measures contributed to an $8 \%$ export growth and a $4 \%$ import decline in 1995, resulting in a marked improvement in the foreign trade account (FTA) and current account (CA) of the balance of payments (BoP). The CA improved from a deficit of $9.5 \%$ to $5.7 \%$ in just a single year.

5. Several measures were introduced aiming at not simply austerity but at the same time a more equitable burden-sharing among strata of society. Social transfers were concentrated on the needy, fees applied to non-life saving medical services and a symbolic tuition fee in higher education.

6. One of the most controversial approaches of the government was the marked reduction of real wages in order to restore labour competitiveness. This measure, labelled heterodox by the IMF, was successful: real wages declined by $11 \%$ on average and $16 \%$ in the public sector.

7. This result was achieved by almost uninterrupted negotiations with the trade unions. They accepted a much smaller nominal wage increase than inflation. It was made clear that the higher the growth of nominal wages, the higher the inflation. To their credit, they accepted the argument.

8. As a consequence of all these consistent measures, Hungary was able to avoid falling into recession again. Instead, there was a real GDP growth of $1.5 \%$ in both 1995 and in 1996. Hence, the specific stabilization program of the government made it possible to break out of the stop-go cycle.

There are two additional steps that, although they did not strictly belong to the stabilization program, are worth mentioning. They constituted a major step towards the modernization of the Hungarian corporate economy. One was the comprehensive privatization of the banking sector and public utilities. It resulted not only in a marked improvement in the quality and scope of financial and public utility services but also in a massive amount of additional fiscal revenue. It is important to mention that the huge amount of privatization receipts stemming from the sale of electricity and gas utilities in 1995 was used to repay public external debt. This masterstroke ${ }^{11}$ contributed significantly to

11 The PM was furious. Nevertheless, the MPs of the coalition supported the proposal of the finance minister. 
the reduction of external debt and dispelled any remaining doubts about the sustainability of financial equilibrium.

The second crucially important structural reform, which - after several years of careful preparations - started in the final year of the second democratically elected government, is the introduction of the multi-pillar pension system with mandatory and voluntary private pillars. ${ }^{12}$ The pension reform created a funded pillar and made it mandatory only for the new entrants to the labour market. Obviously, others were not excluded from joining either. The popularity of the reform is clearly shown by the fact that more than two million already employed people decided to join the second pillar as well. But the success of the reform increased the transitional deficit of the PAYG system. As we will see later, that proved to be a convenient excuse to the second government of Viktor Orbán to shut down the mandatory private pension pillar in 2011.

The second half of the last decade of the last century proved to be a golden age of high rate, investment-driven, export-led, financially sustainable growth. There is no denial of the fact that it created very favourable conditions for the country to start not only real economic convergence but also to join both NATO (1998) and the EU (2004) in the first round of their enlargement. The positive economic and political forces created a hugely beneficial and strong feedback loop. The widespread expectations for a quick recovery and profound change proved to be a self-fulfilling prophecy.

Obviously, not everything was rosy. The rapid transformation was not without its losers, who were longing for the safety and security of the "good old days" of the former "goulash" communist system. Many people could not easily adapt to the new competitive environment for a lack of marketable skills. Abuses of power, corruption in several cases of privatization resulting in undeserved enrichment of insider interests and some political scandals created a fertile ground for the opposition and led to the emergence of an incipient populistnationalist political upswing. This wave of disappointment helped Fidesz to win the parliamentary elections in 1998. Although the next government was a coalition of centreright parties, the anti-market, if not the anti-democracy bias of the gathering populist forces, was clearly visible. The first government of Viktor Orbán (1998-2002) stopped all structural reforms and even tried to reverse some of them (e.g. the pension reform). Fortunately, these efforts proved unsuccessful. The only major turnaround happened in macroeconomic policy. After two years of by and large continuing the prudent fiscal policy of the previous government, PM Orbán responded to the soon unfolding dot-com crisis and the global doom created by the events of $9 / 11,2001$, with a major policy reversal. The era of fiscal alcoholism and economic populism had begun in Hungary at the turn of the 21 st century.

\section{Deterioration (2001-2010)}

The essence of the $U$-turn can be summarized in a single sentence: instead of pursuing (i) export-led, (ii) investment-driven, hence (iii) financially sustainable growth, the new strategy

\footnotetext{
121998 was a crucial year in this regard not only in Hungary but in many other CEE countries. Hungary was the first to introduce a multipillar pension system in 1998 and it was followed by Poland next year, Latvia in 2001, Bulgaria, Croatia and Estonia in 2002, Slovakia in 2005 and finally, Romania in 2008. Interestingly, the Czech Republic started a second, mandatory private pension pillar only in 2012 and Slovenia even later. It shows clearly that in countries where people did not consider the existing PAYG pillar adequate and satisfactory it might have been easier to convince the general public that a multipillar regime was a better option (Holzmann \& Hinz, 2005, pp.150-159).
} 


\section{DISCUSSION}

was to promote (i) consumption-led, (ii) overspending-driven, (iii) borrowing-fuelled, thus (iv) financially unsustainable growth. The decade of deterioration started with this proudly implemented new policy.

The symbol of the new course was the introduction of a two-year budget which contained an enormous $50 \%$ salary increase for civil servants and several additional new spending programs, including heavily subsidized mortgage loans. At the same time, the new governor of the NBH abandoned the last vestige of the monetary stabilization program, the preannounced crawling peg devaluation. The HUF appreciated markedly, which made imports considerably cheaper. Fortunately, improvements in efficiency and export productivity were so large that the economy absorbed this government-induced shock. ${ }^{13}$

Despite various populist and popular measures, the first Fidesz government lost the next election in 2002. It is important to remember why. Instead of indicating a return to consistent economic policy, the opposition Socialists promised even more spending by announcing a program of systemic change in welfare. This was not only an attractive slogan of populist electioneering. They really meant it and started to realize it when they came to power.

The most important elements of the enhanced populist economic program by the government of Péter Medgyessy (2002-2004) can be summarized as follows:

1. In addition to the previous $50 \%$ salary increase to civil servants, the new government extended it to all public employees. Since this group was four times bigger than that of the civil servants, the state budget went into a huge deficit immediately. (Medical staff demonstrated even for more.)

2. The minimum wage was exempted from PIT. In a transition economy, this resulted primarily in more tax avoidance and evasion. A large number of employees officially declared receiving only the minimum wage while they kept getting additional payments under the table.

3. The generous subsidization program for the purchase and construction of housing which had already been initiated by the previous government was somewhat curtailed because of the resulting enormous fiscal deficit. However, the cutback on HUF-loan subsidies created another big problem.

4. Citizens started to raise mortgage loans denominated in foreign currency (primarily CHF but also JPY) in order to benefit from a much lower interest rate. At the same time, the exchange rate risk was transferred completely to the individual borrowers. This became a ticking time bomb (see later).

5. The Medgyessy government introduced the 13th-month pension despite the fact that social security contributions were paid only for 12 months. The propaganda

\footnotetext{
13 The abandonment of the crawling peg devaluation - in essence, a policy of exchange rate manipulation before the term was invented - was a necessary and unavoidable step because the approaching EU accession required the achievement of full currency convertibility. Although full currency convertibility can be consistent with a fixed exchange rate mechanism, excessive central bank intervention in currency markets may not be acceptable for the single market.
} 
was exclusively about what elderly people „deserved” and never about what the PAYG system was capable of financing.

6. All these measures and many more programs of reckless overspending created a situation of twin deficit, i.e. both the general government and the CA accumulated an ever-growing deficit. Neither the private nor the public sector was able to finance its overspending by domestic savings.

7. Medgyessy and his successor ${ }^{14}$ implemented what could be regarded as a strongly pro-cyclical economic policy. Since the economy was performing at full capacity, fiscal stimuli resulted not in ever-higher growth but higher inflation, more imports and a sharp deterioration of financial equilibrium.

8. The mirage of sustainable development was provisionally supported by the increasing amount of EU subsidies. 2004-2008 was a period of global boom that made it possible for many governments (including that of France and Germany) to forget about fiscal prudence almost completely.

In the meantime, a deep political crisis engulfed Hungary right after the 2006 parliamentary elections. ${ }^{15}$ In addition, a referendum against three timid steps of structural reforms was orchestrated by the ever more populist and aggressive opposition. The three issues were (i) visiting fee at a general practitioner, (ii) daily contribution to hospital treatments and (iii) the tuition fee in higher education. (It had already been introduced in 1995). The referendum, held in March 2008, rejected all three, and the government withdrew them immediately. The ship of the Hungarian state became rudderless and was drifting towards bankruptcy. In the unfolding global economic and financial crisis, a CA deficit of $7 \%$ and a correspondingly high level of foreign borrowing was unsustainable. The question was not if, but when, insolvency would set in.

As it has already been mentioned, the Hungarian government was obliged to ask for a bailout one week after the bankruptcy of Lehman Brothers. EUR 20 bn was mobilized by the European Commission (EC), the IMF and the World Bank. After much hesitation, the PM resigned, and he was replaced by a technocrat, Gordon Bajnai, for slightly more than one year of the remaining term of the government. ${ }^{16}$ Bajnai proved to be a highly capable official who successfully stabilized the economy. Public sector salaries were frozen, the 13th-month salary and the 13th-month pension were cancelled, family allowances kept unchanged, housing subsidies restricted. The retirement age was increased to 65 years; the government was contemplating introducing a market value based new real estate tax.

\footnotetext{
14 Péter Medgyessy as prime minister was replaced by Ferenc Gyurcsány in the fall of 2004 in a palace coup within the ruling Socialist party. The change in leadership had nothing to do with the direction of macroeconomic policy. It is proven by the fact that the Gyurcsány government continued the same policy without any hiccup until after the next parliamentary elections which took place in 2006.
}

15 The political crisis was triggered by the publication of a secret speech delivered by the prime minister after the Socialist party had won the elections in 2006. In a presentation, held in a closed session of the Socialist deputies, the PM acknowledged that his government had lied to the people about the economic situation of the country. The speech, replete with expletives, was recorded and smuggled to the political opposition which decided to make it public just before the municipal elections in September, 2006. The fact that the government deceived the voters led to serious rioting in the capital. The headquarters of the public television was torched and robbed. The 50th anniversary of the Hungarian uprising in 1956 was „celebrated” by violence on the streets of Budapest. The unfolding events completely paralyzed the government for the rest of its tenure (Debreczeni, 2012).

16 This was formally an one-party Socialist government supported by the liberals in parliament from without. 


\section{DISCUSSION}

Unfortunately, the short-lived technocratic government had no time and political support to implement reforms. Nevertheless, financial stabilization was a great achievement.

Needless to say that this round of austerity measures were widely unpopular and the intellectual fog about their necessity was deliberately thickened by the irresponsible propaganda of the opposition. As a consequence, many voters felt that Fidesz would come back to power after the next election in April 2010. But few people expected that the rightwing populist-nationalist party would gain a two-thirds majority, and then it would start dismantling the basic institutions of the rule of law and liberal democracy. Analyzing the election program of Fidesz (2009) for 2010, there is no trace of any intention of creating anything like a new regime, let alone something which was later proudly declared an "illiberal democracy". Even in narrowly defined economic issues, the program was concealing intent. While justifiably castigating the socialist governments for driving the country into a deep crisis, there is nothing in the program about further financial stabilization. Instead, there is a detailed description of measures to increase the well-being of the people. The program envisaged significant tax reduction and simplification. Interestingly, it declared joining the euro desirable. A decade later, it is clear that the program was full of rosy and unrealistic proposals and promises which had never been intended to be kept in the first place. Thus, the "big lie” has begun.

In a deep economic and financial crisis, the behaviour of responsible political forces matters even more than at times of smooth sailing. In hindsight, it is clear that few political parties grew up to the task. Fidesz went to extreme populism, and the Socialist party actively helped them to gain a two-thirds majority.

It is an important point. By the time of the 2010 election, the political landscape of Hungary changed fundamentally. A new extreme right, the fascist formation, was established in $2003^{17}$, which failed to get into the parliament in the elections of 2006. Nevertheless, they participated actively in the disturbances and riots which took place in the fall of the same year. For them, it was a godsend occasion to gain prominence and name recognition. Before the next election, the Socialist party decided to distance itself from its former ally, the Free Democrats, who, in turn, formed an electoral alliance with the small MDF for the 2010 elections. In order to increase its own tally, the Socialist party cooperated with Jobbik to block the registration of the candidates of the SZDSZ-MDF alliance. The betrayal was so "successful" that the MDF-SZDSZ alliance could not get into the parliament, and their absence practically resulted in a two-thirds majority of Fidesz. To weigh historical responsibility, it is important to remember that the Socialist party not only pushed the whole country into a deep economic and financial crisis but actively contributed to the sweeping victory of Fidesz (with the two-thirds majority). It made possible the demolition of democracy in Hungary (Bokros, 2019). This represents one of the most tragic and reprehensible moments and aspects of the whole era of political transition in Hungary. It led to the subsequent decade of decay.

\footnotetext{
17 The name of the new party was Jobbik, which stands for Movement for a Better Hungary. It managed to replace a former extreme right nationalist political formation, called Party of Hungarian Justice and Life (MIÉP) which was represented in parliament during the time of the first Fidesz government between 1998 and 2002.
} 


\section{Decay (2010-2020)}

Non-democratic regimes are characterized by the primacy of power politics. The illiberal authoritarianism introduced by the second, further expanded by the third and fourth Orbán governments, is such a system. The political and personal interests of a tightly knit oligarchy determine not only the scope and shape of political institutions but those of the economy, law, culture, ethics, etc. too. In a sense, this is a wholesale reversal of the postcommunist transition which used to be a process of modernization where the economy, as well as all other important spheres of societal existence, regain their autonomy or relative independence. ${ }^{18}$

If the process of transition can rightly be called development, then it went into reverse in Hungary in the last decade. Politics, raw personal interests and crude ideology captured and superimposed themselves on the economy, society, culture and ethics again. The decay of modernization, as represented by the reversal of transition, can be regarded as a return to anti-modernity. ${ }^{19}$

By accepting that an authoritarian regime is strongly conditioned by politics and ideology, it is relevant to start its characterization by its politics and ideology. Hence, before describing its economic policy and performance, it is important to discuss its politics and ideology. Political economy helps us in this endeavour.

\subsection{The Abolition of the Rule of Law}

Once the second Orbán government took office, it initiated sweeping changes in the legal system of Hungary. In the first one and half years of its rule, 356 laws were created or changed. The most important among them was to prepare and accept a new constitution, wholly without parliamentary debate or consensus. The new constitution, called Basic Law (reflecting upon the name of the German Grundgesetz) was approved on April 25, 2011, hardly one year after Fidesz had won the parliamentary elections. ${ }^{20}$ It came into force on January 1, 2012.

This essay is not about constitutional issues. Suffice to indicate only two things that reflect the degree of decay wrought upon the Hungarian polity by Fidesz. One is expressed by its language and even by its title: instead of calling it the Basic Law of the Republic, it is proclaimed to be the Basic Law of Hungary. The former official name of the state is replaced by the name of the country in the whole text as if the two would be the same. It is

\footnotetext{
18 „While in communism the political sphere was more important than the economic one, it is not to say that in capitalism this is the other way round. The interplay between politics and economics in capitalism is more subtle, stochastic, nuanced and balanced." (Bokros, 2013, p.58).

19 Today there is no consensus among Hungarian intellectuals about the origin and nature of the Orbán regime. Some say that the Orbán-led group of ruling politicians is primarily a criminal organization which, by capturing the state, transformed it into a mafia state. That view ignores the role of ideology (Magyar, 2016). Others maintain that what is termed "illiberal democracy" by their owners is a visible example of a fascistoid mutation. See e.g. Ungváry (2014). I agree with the latter approach because I accept that (i) the system does have a clearly detectable ideology and (ii) many of its policy measures directly reflect this harmful ideology.

20 The first round of the parliamentary elections in Hungary were held on Sunday, April 11, 2010, one day after the tragic crash of the plane which transported high ranking Polish dignitaries to Smolensk, Russia to visit the site of the infamous Katyn massacre. The auspices for the outcome of the election were not favorable in Hungary.
} 


\section{DISCUSSION}

a distortion with a clear purpose: the regime always insists on identifying itself with the whole country. ${ }^{21}$

Second, the Basic Law, which originally had been labelled by the government as „rock solid", and expected to remain unchanged for a long period of time, has already been modified nine times in the last decade. On each and every occasion, the amendment was drafted and accepted by the parliament within a week. If a government keeps ignoring not only society but the legislature in such a blatant manner when changing the most important piece of law of the country, that alone speaks volumes about the degradation of parliamentary democracy.

The most important changes which resulted in the complete abolition of the checks and balances of a state based on the rule of law are the following:

1. Significant restrictions on press freedom were legislated as early as June 2010 . The government gradually extinguished all sources of critical media. Today all daily papers and TV channels follow government instructions. Independent radio broadcasters are constantly harrassed (e.g. Klubrádió).

2. The Constitutional Court's (CC) jurisdiction was severely restricted: it can no longer intervene in important areas of social life such as fiscal affairs, taxation, etc. All members of the CC have been appointed by Fidesz. The CC ceased to function as a restrictive force to government omnipotence.

3. Instead of proportional representation, the electoral system has been transformed into a first-past-the-post which gives substantial bonus votes even to the winner. Opposition parties are forced to unite and field single joint candidates in each constituency, an almost impossible task.

4. The president of the republic, that of the State Audit Office and that of the Supreme Court are exclusively Fidesz appointees. The chief prosecutor's office is completely subordinated to the government. Prosecutors always refuse to start even an investigation on alleged government corruption.

5. The independence of the judiciary is curtailed by the new National Judicial Council and National Judicial Office. Its president, a Fidesz appointee, can reshuffle specific cases among courts, establish benefits and penalties for judges at will, etc. The independence of the judiciary is largely lost.

6. The president of the NBH and that of the Economic Competition Office (ECO) are personal loyalists of Orbán, and they follow whatever is expected from them. Both institutions lost their autonomy. None of them constitutes checks and balances in Hungarian economic life any longer.

7. The government established a centralized bureaucracy to control public education and took over public schools from their former sub-sovereign owners. Appointment

21 The brutal distortion is reflected regularly in government propaganda when political opposition figures are labeled as traitors of the fatherland or enemy of the people, or when the government claims that the "fatherland cannot be in opposition". By implication, the government projects itself to be identical to the fatherland. 
and dismissal of teachers and educators are now the sole prerogatives of the central government in all public schools.

8. Academic freedom has been severely curtailed. Orbán expelled the CEU from Hungary, created pseudo-private endowments for public universities with boards appointed exclusively by the government, and took control of the research institutes of the Hungarian Academy of Sciences (HAS).

These are just examples of government intrusion into important areas of social life which are supposed to be autonomous or outright independent from heavy-handed interference of the executive. But even these few examples show very clearly that liberal democracy, with the rule of law operating with institutional checks and balances, has already been lost in Hungary. ${ }^{22}$

Despite being a member of both NATO and the EU, Hungary today is no longer a functioning parliamentary democracy. There is no such thing as an illiberal democracy. The entire system of checks and balances, an integral part of the rule of law, has been demolished. The facade of democracy may have survived, but institutions have been reduced to empty shells and are unable to uphold the rule of law. ${ }^{23}$ In fact, the law has become completely subordinated to the short term exigencies of personal power politics. It is a striking similarity with the former communist system, where legislation and jurisprudence were ancilla politicae. The country's political and even its cultural life is in the ever-tightening grip of a power-hungry and corrupt oligarchy. No wonder that Hungary is lagging behind other CEE countries in economic competitiveness and convergence, too.

\subsection{Institutional Decay in the economy}

Given such an unfavourable legal and political environment, it is no surprise that market institutions have suffered irreparable damage. Authoritarian regimes may decide to preserve some of the main ingredients of the rule of law in order to maintain a flourishing market economy. But it seldom happens, and it cannot last long. ${ }^{24}$ In Hungary, it did not survive the onslaught by the government.

The most important measures which have substantially contributed either to the (i) demolition or to (ii) serious distortions of the market economy in Hungary can be summarized as follows:

1. The Orbán government abolished the mandatory private pillar of the new pension system in 2010-2011, thus reversing one of the most fundamental and significant reforms of the transition drive. Four aspects are especially notable. First, it was initiated as blackmail: the finance minister declared that those who fail to go back

22 It is important to write this sentence in present perfect tense. Contrary to statements of leading persons of the European People's Party (EPP) that several measures implemented by the government may "threaten" the rule of law in Hungary, it is necessary to realize that the rule of law has already been destroyed. Therefore, any sanction which may come into force as a consequence of new measures by the government misses the point. For the authoritarian regime which proudly declares itself illiberal, there is no need to implement new measures; what has already been done is more than sufficient to perpetuate the anti-democratic regime and its power.

23 That is why the famous Hungarian scholar, Rudolf Ungvary is right when he emphasizes the concealing and concealed, i.e. stealth nature of the Hungarian fascistoid regime established by Orbán (Ungváry, 2014).

24 The best contemporary example is Hong Kong. The rule of law is simply incompatible with autocracy. 
to the PAYG would lose their claim for a state pension despite having contributed to the social security system. ${ }^{25}$ Second, the action was required from those who wished to stay in the private pillar; those who accepted the government's initiative did not have to act. Third, the amount of private pension savings accumulated in the pension funds of the mandatory pillar was confiscated. It was close to $12 \%$ of GDP. Fourth, the government did not spend all of the confiscated funds on debt removal; a good part of it was used to finance current spending.

2. The government initiated and carried out a sweeping renationalization of private enterprises, especially in sectors where (i) firms cannot leave the market, (ii) have little or no export potential and (iii) have a constant and stable revenue stream. These are primarily the public utilities and banks. ${ }^{26}$ Most of the enterprises belonging to these sectors were in foreign hands. The government explained its move by declaring that so-called "strategic sectors" needed to be in national, even more, in state ownership. Again, four characteristics should be highlighted. First, the government grossly overpaid the former private owners who were more than happy to sell their property at an inflated price. Second, regulation was immediately changed in order to keep utility prices low or even reduce them. ${ }^{27}$ Third, price subsidies distorted the market, destroyed incentives to efficiency, depleted investments and made profitability unnecessary. Fourth, once a firm is a loss-maker, it is easier to use it as a cash cow by special interests.

3. Instead of simplifying the tax system, the government introduced a whole host of sectoral taxes in order to punish them for allegedly monopolistic behaviour. Telecom, banking, retail trade, utilities, network infrastructure, and advertising fell under the regulatory wrath of the illiberal regime. Many of these punitive taxes were introduced with the intention to chase away foreign owners; this was just a preparatory move for nationalization. Two aspects are worth mentioning here. First, the logic of communism was followed again: it was exactly what the communists did after WWII in Hungary. Second, punitive sectoral taxes were applied together with fast proliferating and highly individualized subsidies. Obviously, the result is a significant market distortion, but that was precisely the objective: instead of thriving in a free market, private entrepreneurs are taught to seek the favours of the government or at least behave in such a way that they can avoid the punishment which would destroy their livelihood and property.

\footnotetext{
25 Of course, that was not true because it could not have been true. But people did not and could not figure that out in advance. The arrogance and purposefully misleading content of the statement of the finance minister reflects perfectly the unlimited unscrupulousness and fundamental dishonesty of the regime.
}

26 They may have read my previous book where I singled out public utilities and financial sector firms from mainstream privatization for their need of restructuring and re-regulation before any privatization transaction could take place. The underlying characteristics of these sectors work both ways: either in privatization or in nationalization. (Bokros, 2013, pp.102-126).

27 This led to the infamous slogan of „utility fee reduction” (rezsicsökkentés) which worked wonders in the next election, especially among low income retired people despite the fact that price subsidies tend to benefit much more affluent people. See later by (Debreczeni, 2012) and footnote 32. 
4. The same "stick and carrot" approach is used in the largest fiscal income redistribution machinery under direct state control: public procurement. Three basic characteristics of this area need to be mentioned. First, the influence of the central government in the mechanism is further enhanced by emptying out the sub-sovereign governments. Second, the amount of EU subsidies is so large that even a responsible and prudent government would have a hard time spending it properly and efficiently. Third, as a consequence of all the above, public procurement has become the most important and visible hotbed of corruption where the regime selects only its oligarchic friends as winners and sends out the message that one can be successful only if being part of the corrupt mechanism of state capture. Moreover, EU subsidies have created intensive aid-dependency, which in itself is a serious market distortion. More important, EU subsidies make the regime financially sustainable and contribute to corruption.

5. It might be a shocking statement, but corruption and cheating is the main drive of monetary policy, too. The NBH has kept its base rate extremely low for more than five years, including in the period of significant inflation. The stated objective has been to stimulate growth, which, again, was unnecessarily pro-cyclical before the crisis of 2020. However, the real goal was very different: allowing the HUF to depreciate. Marked loss of the HUF value creates a profit on foreign exchange reserves which serves a double purpose. First, profitability can be declared a sign of operating efficiency. Second, despite clear legal requirements, profit has not been paid to the central budget but set aside in private endowments for intransparent use.

6. Perpetuating the smooth functioning of this corrupt mechanism is the primary reason why the government has no intention to give up the HUF, the national currency. Needless to say that the real reason is concealed by misleading nationalist-populist propaganda. ${ }^{28}$ Moreover, avoiding euro-accession is easy: it needs only non-compliance with the existing, albeit somewhat hesitantly enforced accession criteria. But there is a high price to pay: the uninterrupted depreciation of the HUF makes a mockery of most, if not all, wage and salary growth. Furthermore, the loss of the international value of the HUF pushes up inflation in a small, open economy dependent on imports. That takes back a good part of nominal wage rises, too. In other words, employees are obliged to pay for the cost of government-sanctioned official corruption.

7. The constant depreciation of the HUF is beneficial to the export sector. It is dominated by foreign strategic investors. Growing export revenues are there to compensate for the loss of competitiveness resulting from the policy. This compensatory mechanism is important because the government deliberately surrendered the manufacturing industry to foreign capital. There are two reasons for that; one is economical, another is political. An economy made uncompetitive by heavy-handed intervention is incapable of large productivity and efficiency

${ }^{28}$ The main line of reasoning of the government and the $\mathrm{NBH}$ is to preserve national sovereignty and, within that, monetary sovereignty. Few people understand that in a country which has already achieved full currency convertibility and is part of a single market with completely free flow of capital, monetary sovereignty is largely a thing of the past. Under these circumstances, the only significant remaining sovereign instrument to be used by the central bank at its discretion is the policy interest rate (Bokros, 2021b). 
gains, no matter how much lip service is paid to the importance of R\&D and how much fiscal resources are spent on it. The political factor is equally important: foreign capital has a stake in the continuation of a regime, offering them significant material benefits.

8. Nationalization was supplemented with monopolization in a number of sectors leading to further market distortions. The first was the monopoly in the retail trade of tobacco and tobacco products. It also helped create a large number of small beneficiaries of privileges. They are expected to be staunch supporters of the anticompetition economic and political regime. Next was the monopolization in the publishing of basic school textbooks. This move conveniently led to the "streamlining" of educational content, too. Since public schools are instructed to use particular textbooks anyway, academic freedom is severely curtailed. This is a primary example of the strong interlinkages between economic and political monopolization.

9. The government was quick in emptying out sub-sovereign governments. Local governments had to give up the ownership of institutions in public education and health care. The provision of basic public services constituted the backbone of their legitimacy. In addition, the centralization ${ }^{29}$ of the provision of public services in the hands of the central government killed whatever competition there might have been and severely limited public choice. No surprise, therefore, that there is a constant deterioration in the quality of public services, especially education and health care in Hungary. A desirable byproduct of this centralization for the government is the fatal weakening of local democracy. The decay was further exacerbated by the threat coming from prominent figures of Fidesz that if local society wanted to get more funds from the central government, local voters had better elect a local assembly and mayor who would be from Fidesz and, hence, would have excellent political contacts with the central government. This blatant regularly and unscrupulously expressed threat shows very clearly the degree of degeneration of democracy and political culture in Hungary.

10. It is worth remembering the "solution" the government applied to the bankruptcy of hundreds of thousands of people who had defaulted on their foreign currencydenominated mortgage debt. It was conveniently forgotten that foreign currencydenominated mortgage lending gained traction for the first time when the Socialist government was obliged to limit the interest subsidies which had been generously offered by the first Fidesz government. After the sharp devaluation of the HUF in 2008, hundreds of thousands of people realized that their debt calculated in HUF skyrocketed despite having serviced it for several years. No doubt, the government had to act, but it decided to put all the burden on the banks. Since most of the banks were foreign-owned at that time, it was a popular move to

29 It is important to recognize that it is centralization and not nationalization, because subsovereign governments are part of the state; they are definitely not private actors or economic agents. Nevertheless, decentralization in the provision of public services is important. Local governments can act as checks and balances within the state. 
concentrate all the losses on them. The banks incurred enormous losses and were recapitalized by their mostly foreign owners. One might think that it was a smart move, but it is important to notice that the exceptionally one-sided and aggressively pursued solution badly damaged the trust in markets in general and in banking in particular. Shrill populist rhetoric against financial institutions has remained part and parcel of populist-nationalist propaganda ever since. ${ }^{30}$

11. Finally, it needs to be highlighted that support for the more affluent people has become a proudly displayed hallmark of the authoritarian regime. First, it introduced a single rate for the PIT, which was reduced to $16 \%$ and later to $15 \%$. Second, in order to compensate for the lost fiscal revenue, it increased the marginal rate of the VAT to $27 \%$, the highest level in the world. Third, most important, almost all social support was incorporated into the PIT, which is a hugely unfair burden-sharing and against social solidarity. People who do not work or have no taxable income are unable to benefit from these measures. It is primarily targeted against the Roma population. They have little registered employment but at the same time have large families. One of the most recent measures clearly reflecting the racist and anti-poor bias of the government is the exemption of women from PIT for life who have at least four children. It gives nothing to those who take care of their children at home and earn nothing while supports those affluent women who happen to have high salary jobs and can afford domestic help. (It is important to note that the PM has five children.) Conversely, family allowances, offered on the basis of universal entitlement, have remained unchanged at an extremely low level for the entire decade. ${ }^{31}$

12. There are many more measures introduced by the authoritarian regime in the last decade, which reflect strong anti-liberal or anti-social ideology. All of them lead to the conclusion that the ruling party is against the free market, competition, independent entrepreneurship and private property protected by the state based on the rule of law. Instead of serving a society of well educated and highly capable, autonomous, responsible citizens, Viktor Orbán is interested in creating servile dependants (Untertanen) who happily give up their freedom and civic engagement in exchange of the safety and security allegedly provided by the authoritarian regime. Political subjugation always comes first: entrepreneurs, property owners, employees, recipients of subsidies are kept insecure in their possession unless they accept the rule of the oligarchy, which captured and annexed the state. The only individual escape route is emigration. And that is key. So long as the borders are open and the HUF is convertible, the last vestiges of personal autonomy are preserved. That is why the regime is not (yet) an autocracy but an ideologically driven and corrupt authoritarian one.

Of course, one should ask the legitimate question of whether such a dirigiste, etatist, monopolizing and nationalizing, anti-market, the anti-competition and anti-social post-

\footnotetext{
30 The best description of what happened in Poland, Romania and Hungary can be found in Hudecz (2012).

${ }^{31}$ In the second point of this subsection, reference has already been made to the utility fee reduction which also has a strong anti-poor bias. People having a swimming pool can benefit from artificially low gas and electricity prices infinitely more than those who have only an one-room flat or no dwelling at all. See also footnote 28.
} 


\section{DISCUSSION}

communist regime could deliver better outcomes in growth, financial stability, and higher living standards, not to mention convergence to Western productivity and efficiency, than a government conducting a liberal economic and well-targeted social policy while upholding the rule of law. ${ }^{32}$

On the face of it, it looks like Hungary had a rather positive decade between 2010 and 2019. Growth was relatively high between 2014-2019, in the period of the global boom, but not particularly high, especially not compared to the V4. After a stagnation and slow recuperation in the post-crisis period, with even a decline of $1.5 \%$ in 2012 , real GDP growth was as follows: 2014: 4.2\%; 2015: 3.8\%; 2016: 2.2\%; 2017: 4.3\%; 2018: 5.1\%; 2019: 4.9\%. Due to high-quality export goods produced first and foremost by efficient foreign manufacturing enterprises, the FTA always showed a surplus. Due to the enormous and fast-growing amount of EU subsidies (3-5\% of GDP), the CA was in surplus in this period, too. Economic growth and fiscal support for job creation resulted in a higher employment rate (from below 50\% in 2012 to above $60 \%$ in 2018) and a lower unemployment rate (from above $10 \%$ in 2012 to below $4 \%$ in 2019). Inflation, in turn, has remained persistently high due to the pro-cyclical policies (it was hovering around $4 \%$ and had been increasing even further recently). Fiscal prudence and rectitude, never a forte of Fidesz, resulted constantly in a deficit (remaining above $4 \%$ in bad, but still above $2 \%$ of GDP in good times). That is a reflection of anti-cyclical policies in recession but pro-cyclical bias in high growth periods. Although the public debt has come down by more than $12 \%$ point (from above $80 \%$ to below $70 \%$ of GDP) in the second half of the decade, it was due to the high growth and lowinterest-rate environment. ${ }^{33}$ At the same time, domestic savings and private investments remained rather low, resulting in low growth or stagnation of productivity and efficiency (Csillag, 2020).

\section{Concluding remarks}

This brief summary shows that Hungary made some considerable progress in growth, but it did not lead to convergence. The historic goal remains elusive. The most important reasons for that are the serious distortions of the recently reconstituted capitalist market economy (by nationalization, monopolization, protectionism, state capture, etc.) and, first and foremost, the deliberate and methodical destruction of the rule of law. After the wholesale establishment of a self-styled „illiberal democracy” which is nothing but a thinly disguised authoritarian regime, the last ten years can be considered a lost decade. Although, as a member of the EU, Hungary cannot become a closed economy and closed society. Hence,

\footnotetext{
32 This statement is important because there are many left-leaning opposition figures and intellectuals in Hungary who mistake the economic policy of the Orbán-regime for a "neoliberal” one and they demand Socialist policies (Halmai, 2020). It is a fundamental misunderstanding to consider the economic policy of the current regime neoliberal - or, for that matter, neoconservative - because liberals and conservatives not only preserve but keep strengthening private property, market institutions and the rule of law. The same misconception is reflected in hundreds of Western newspaper articles which characterize the Orbán-government as conservative nationalist. While the nationalist epithet is adequate, the conservative is wide of the mark. Likewise, a nationalist like Donald Trump was absolutely not a traditional, small state, low deficit conservative, but a radical populist who captured the Grand Old Party (GOP) and transformed it into a machinery serving his own personal interests. No wonder that Orbán wanted to be a close friend of Trump and even echoed his big lie about the election steal.

33 This summary analysis does not reflect the impact of the 2020 economic crisis.
} 
so long as EU membership remains, totalitarian autocracy is probably excluded from the alternatives of future developments; further decay is not. The degeneration of the free market into a politically supercharged and manipulated arena, where success and profit for domestic entrepreneurs are determined by permanently manifested political loyalty rather than efficiency and productivity, real convergence even in narrowly defined economic terms remains largely unattainable. No matter how much the Orbán-regime tries to ally itself with China, Russia, Turkey and Azerbaijan, these countries are not providing attractive alternatives for civilization ideals. For economic convergence to happen, a constitutionally limited, transparent, democratic, accountable and at the same time high-quality state needs to be rebuilt in which people will, and wish to, invest their trust and confidence. The ugly nationalist-populist authoritarian system needs to be dismantled. Transition to a market economy and liberal democracy has to start again.

\section{Acknowledgement}

This short essay has benefited considerably from the generous comments of two distinguished scholars, Tamás Bauer and István Csillag, principal and honest leaders of the economic and political transformation of Hungary in the first twenty years of its genuine transition. Their constructive contribution is gratefully acknowledged by the author.

\section{References}

Balcerowicz, L. (1995). Socialism, Capitalism, Transformation. CEU Press.

Berend, I. T. (2010). The Hungarian Economic Reforms 1953-1988. Cambridge University Press

Bokros, L. (1998). Stabilization without Recession. The Success of a Long-Awaited Financial Adjustment in Hungary. In Scheherazade, R. (ed.). Financial Crisis Management in Regional Blocks. Kluwer Academic Publishers.

Bokros, L. (2013). Accidental Occidental. Economics and Culture of Transition in Mitteleuropa, The Baltic and Balkan Area. CEU Press.

Bokros, L. (2014). Regression. Reform Reversal in Hungary after a Promising Start. In Aslund, A. \& Djankov, S (eds.). The Great Rebirth. Lessons from the Victory of Capitalism over Communism. Peterson Institute for International Economics.

Bokros, L. (2015). Hanyatlás. (Decay) Élet és Irodalom, No. 1-2. Budapest

Bokros, L. (2019). Szabadság és Szolidaritás. (Freedom and Solidarity) Élet és Irodalom, Budapest

Bokros, L. (2021a). Socialism - The Tragedy of an Idea. Possible? Inevitable? Desirable? Springer Nature.

Bokros, L. (2021b). Az újjáépítés csiszolatlan sarokkövei. I. Állami pénz és költségvetés (The rough cornerstones of reconstruction. I. State money and budget) Élet és Irodalom, No.6., Budapest.

Brown, A. (2010). The Rise \& Fall of Comunism. Vintage Books.

Csillag, I. (2020). Beyond the first glimpse (Analysis of the economic policy in Hungary from 1998). Acta Oeconomica, 70(3), 333-360.

Debreczeni, J. (2012). A 2006-os ösz (The Fall of 2006). DeHuKönyv.

de Tocqueville, A. (2008). The Ancient Régime and the Revolution. Penguin Classics.

Fidesz. (2009). Választási program (Election program). 


\section{DISCUSSION}

Gati, C. (2006). Lost Illusions. Moscow, Washington, Budapest and the 1956 Hungarian Revolution. Woodrow Wilson Center Press and Stanford University Press.

Halmai, G. (2020). Trump és Orbán (Trump and Orbán) Élet és Irodalom, No. 51-52. Budapest.

Holzmann, R., \& Hinz, R. (2005), Old Age Income Support in the 21st Century. The World Bank,

Hudecz, A, (2012), Párhuzamos történetek. A lakossági devizahitelezés kialakulása és kezelése Lengyelországban, Romániában és Magyarországon (Parallel stories. The development and treatment of household foreign-currency lending in Poland, Romania and Hungary) Közgazdasági Szemle, Vol. LIX.

Ježek, T (1997). The Czechoslovak Experience with Privatization. Journal of Economic Affairs, 477488.

Kornai, J. (1997). Editorial: Reforming the Welfare State in Postsocialist Societies. World Development, 25(8), 1183-1186.

Kornai, J. (2008). From Socialism to Capitalism. Eight Essays. CEU Press.

Lomax, B. (1976). Hungary, 1956. Allison \& Busby.

Magyar, B. (2016). Post-Communist Mafia State. The Case of Hungary. CEU Press.

Mong, A. (2012). Kádár hitele (Kádár's loan). Libri.

Tökés, R. L. (1996). Hungary's Negotiated Revolution: Economic reform, social change and political succession. Cambridge University Press

Ungváry, R. (2014). A láthatatlan valóság. A fasisztoid mutáció a mai Magyarországon (The invisible reality. The fascistoid mutation in contemporary Hungary). Kalligram.

The discussion paper passed the review process. | Received: February 23, 2021; Revised: May 11, 2021; Accepted: May 19, 2021; Published: June 1, 2021. 